\title{
New record of the starfish Ophidiaster ludwigi (Echinodermata: Asteroidea) from the Pacific of Mexico and Costa Rica
}

\author{
Carolina Martín-Cao-Romero' ${ }^{1}$, Francisco Alonso Solís-Marín², Juan José Alvarado 3 \\ $\&$ Alfredo Laguarda-Figueras ${ }^{2}$ \\ 1. Posgrado de Ciencias del Mar y Limnología, Universidad Nacional Autónoma de México (UNAM); \\ caromcr@gmail.com \\ 2. Laboratorio de Sistemática y Ecología de Equinodermos, Instituto de Ciencias del Mar y Limnología (ICML), \\ UNAM, Apdo. Post. 70-305, México City, CP. 04510, México; fasolis@cmarl.unam.mx, laguarda@cmarl.unam.mx \\ 3. Centro de Investigación en Ciencias del Mar y Limnología (CIMAR), Universidad de Costa Rica; 11501-2060, San \\ José, Costa Rica; juan.alvarado@ucr.ac.cr
}

\section{Received 13-I-2017. Corrected 29-IV-2017. Accepted 02-V-2017.}

\begin{abstract}
Ophidiaster ludwigi had been reported only from Panama and Peru. Here we add record of the genus and species for Mexico and Costa Rica; and, first time its bathymetric distribution (0-156m). Rev. Biol. Trop. 65(Suppl. 1): S253-S257. Epub 2017 November 01.
\end{abstract}

Key words: Asteroidea; Pacific; Mexico; Costa Rica; new record.

The family Ophidiasteridae Verrill, 1870 comprises 28 valid genera, is mainly shallowwater, tropical and subtropical family. The species are conspicuous feature in coral reef fauna. Asexual reproduction by fission occurs in a few species, but normally fertilization, planktotrophic or lecithotrophic larvae, and bipinnaria and/or brachiolaria stages are more common (Mortensen, 1921).

The species of the genus Ophidiaster can be distinguish by a small disc, arms moderately long, cylindrical, rarely tapering; abactinal plates in regular longitudinal and transverse series; skin uniformly granulose; popular areas in eight longitudinal series, one series each side below inferomarginal plates; pedicellariae, when present, sugartongs form in well-developed alveoli (Clark \& Downey, 1992). There are 24 valid species of this genus distributed world-wide, but only two of them had been reported for the eastern Pacific coast: Ophidiaster agassizi Perrier 1881, only found in
Chile and $O$. ludwigi, this species had been reported for Panama and Peru (Pérez-Ruzafa et al., 2013).

\section{MATERIAL AND METHODS}

The Ophidiaster ludwigi de Loriol, 1900 specimens are deposited in the Colección Nacional de Equinodermos "Dra. María Elena Caso Muñoz" (ENC, ICML, UNAM) and in the Museo de Zoología de la Universidad de Costa Rica (MZUCR).

The identity of the specimens of $O$. ludwigi de Loriol, 1900 was determined on the basis of the diagnostic characters described in de Loriol, 1900. Pictures of taxonomical characters of the species were taken using a multifocal microscope AXIO Zoom.V16 with the camera AxioCam MRc5 and the program Zeiss Efficient Navigation, at the Microscope Laboratory (Instituto de Biología, UNAM). 


\section{RESULTS}

\section{Systematics}

Class Asteroidea de Blainville, 1830

Order Valvatida Perrier, 1884

Family Ophidiasteridae Verrill, 1870

Genus Ophidiaster L. Agassiz, 1836

Ophidiaster ludwigi de Loriol, 1900 (Fig. 1)

Diagnosis: Disc slightly expanded, convex, rounded compound plates, little prominent, loosely arranged in circles around two or three central plates.

Material examined: Six specimens "Piedras próximas a la Playa La Rocosa, Puerto Vallarta, Jalisco $\left(20^{\circ} 40^{\prime} \mathrm{N}, 105^{\circ} 15^{\prime} \mathrm{W}\right)$, January 10th 1951 (ICML-UNAM 2.11.1). (Fig. 2). One specimen, Isla del Coco, Costa Rica $\left(05^{\circ} 34.670^{\prime} \mathrm{N}, 87^{\circ} 03.473^{\prime} \mathrm{W}\right)$, November 11 th 2013, 156 m (MZUCR-1264).

Description: $\mathrm{R}=13.32 \mathrm{~mm} \mathrm{r}=2.85 \mathrm{~mm}$, five rounded, relatively short, thick and obtuse (blunt) arms; wide at the base, very gradually reduced until ending in a blunt point. A small upper flat plate having one to three small tubercles, without granules at the end of ambulacral groove. There are seven rows of main skeletal plates, five in the dorsal side, and two along the underside of each side. These plates appear on the oblong, transverse, compressed and slightly bulging surface, are relatively inconspicuous and form regular series until about two-thirds the length of the arm. These regular series are separated by groups of parallel papular limited areas not well-defined depressions. There are, in each, from 18 to 20 pores embedded in the granules. One series of papular areas bordering on the ventral side, the last series of plates are much less limited and contain from seven to eight of them. Entire surface is covered with rounded granules or prismatic relatively thin, uneven, with some warts microscopic. Abactinal surface granules are scarce and more developed than the actinal ones. Narrow ambulacral furrow; it is bordered by a unique series of short spines, flattened and truncated at the end; a number of them, without alternating steady, half are closer than others, but the same length; no separated granules inside the groove, they close to each other, stout. Anal orifice is central. Madreporic plate rounded, quite flush with the granulation.

Literature survey and museum records indicated that the northernmost record of $O$. ludwigi in the eastern Pacific is off Panama, based on a specimen present in the Invertebrate Zoology Collections (Echinoderms) of the National Museum of Natural History, Washington (USNM E7592), collected in March 1848 in Gulf of Panama. The new record here presented for Puerto Vallarta, Jalisco, Mexico was located northern of the previous location.

\section{DISCUSSION}

The finding of O. ludwigi de Loriol, 1900 at Puerto Vallarta, several thousand kilometers north of the previously recognized northern limit, is important as it increases the species number of known asteroids present at the western coast of Mexico to 50 (Honey-Escandón Solís-Marín, \& Laguarda-Figueras, 2008). The observed specimen (Fig. 1) has major radius between 13-32 $\mathrm{mm}$ and minor radius between 2.2-6.54 mm.

It should be noted that the brief description of $O$. ludwigi de Loriol, 1900, based on a small specimen $(\mathrm{R}=40, \mathrm{r}=9)$ has been suggested as a Pharia pyramidata Gray, 1840 juvenile (de Loriol, 1900). The type locality ("Perou”) may indicate an origin in the Gilbert Islands instead of South America (Clark, 1910). In addition, F. Ziesenhenne notes in the card catalog of LACM (Los Angeles County Museum): "Ophidiaster ludwigi de Loriol type was sent to the [Allan Hancock] Foundation and is a stubby rayed Pharia pyramidata (Gray, 1840)" (Hendler, 1996).

Description of this species was based upon a single specimen in de Loriol's collection, labeled simply "Perou". $\mathrm{R}=40 \mathrm{~mm}$., $\mathrm{r}=9 \mathrm{~mm}$. Rays, $11 \mathrm{~mm}$. broad and $8 \mathrm{~mm}$. high at base. Color brownish violet; papular areas lighter; 


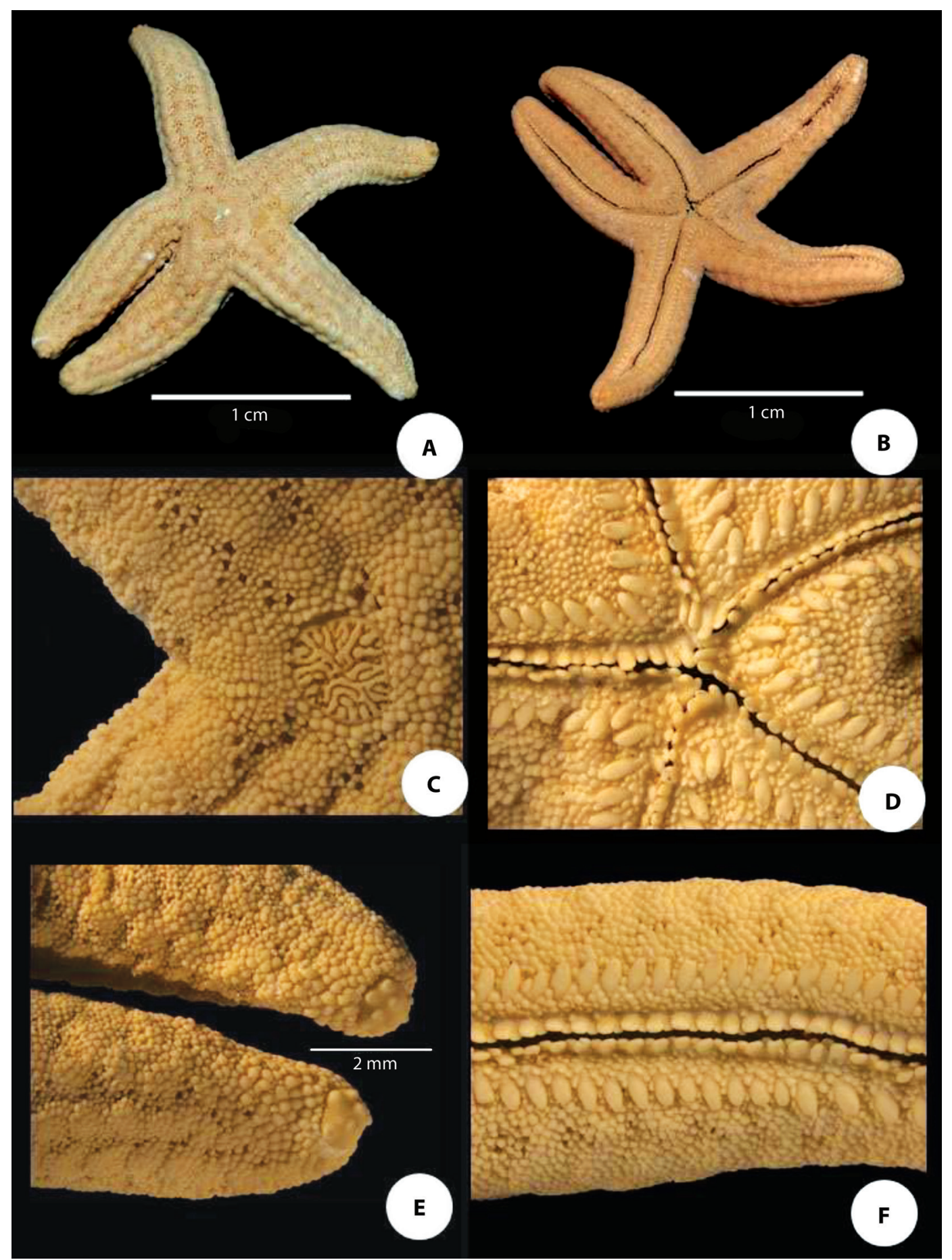

Fig. 1. Ophidiaster ludwigi. ICML-UNAM 2.11.1. A) Abactinal view; B) Actinal view; C) Madreporic plate; D) Oral plates; E) Detail of terminal plates; F) Ambulacral furrow. 


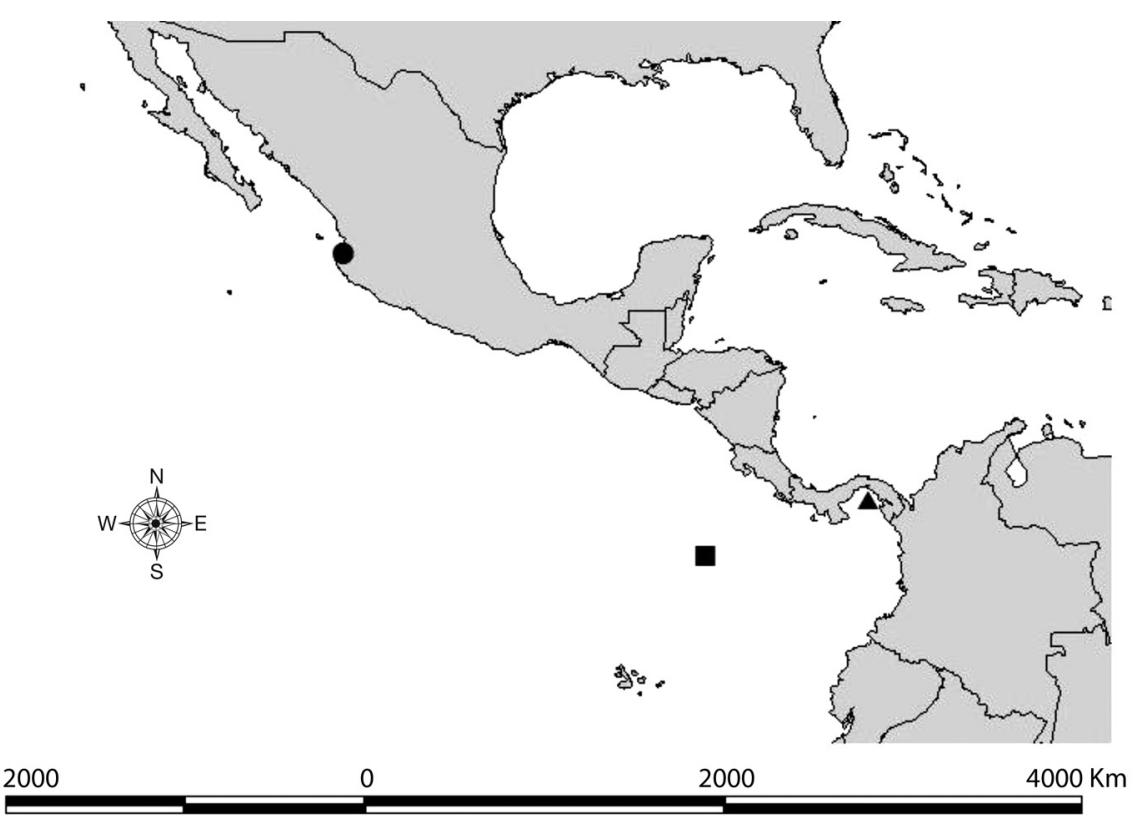

Fig. 2. Map showing the known records of Ophidiaster ludwigi, ( $\boldsymbol{\Delta}$ ) previous record (Gulf of Panama); ( $\bullet$ ) new record in the Mexican Pacific; ( $)$ new record in the Pacific coast of Costa Rica.

ventral side, pale yellowish. While at least one species of Ophidiaster may occur in the warmer coastal waters of Peru, it should be remembered that many animals, described in Europe as from Peru, were really from the island of Peru in the Gilbert group, and it is quite possible therefore that de Loriol's Ophidiaster is not from South America (H. L. Clark, 1910).

According with Hendler (1996) the differences between $P$. pyramidata and $O$. ludwigi are that Pharia has a very large madreporic plate (diameter 0.25 or more of disc diameter), rays somewhat trigonal, inner series of adambulacral armature made up of approximately equal and similar spines. Instead of that, $O$. ludwigi has a much smaller madreporic plate, rays more or less cylindrical, inner series of adambulacral armature made up of alternating large and small spines.

Ziesenhenne (1963) presented Ophidiaster easterensis as a new specie reported from $\mathrm{La}$ Perouse Bay, Eastern Island. According to that paper $O$. ludwigi differs from $O$. easterensis in the sunken papular areas, tumid abactinal plates, uniform distribution of sharp actinal spines, smaller terminal plates, absence of granules on the furrow spinelets, and fewer and different pedicellariae.

The present study represents the first record of the genus and the species for Ophidiaster ludwigi de Loriol, 1900 for the Mexican and Costa Rican Pacific coasts. This is the first time that bathymetric data is provided $(156 \mathrm{~m})$ for this species.

\section{ACKNOWLEDGMENTS}

To Susana Guzmán (Laboratorio de Microscopía, Instituto de Biología, UNAM) for her technical support during the photographic sessions. We are grateful to Alicia Durán and Ma. Esther Diupotex (ICML, UNAM) for their technical support at the ENC, ICML, UNAM.

\section{RESUMEN}

New record of the starfish Ophidiaster ludwigi (Echinodermata: Asteroidea) from the Pacific of Mexico and Costa Rica. Ophidiaster ludwigi ha sido registrado solo para Panama y Perú. Aquí nosotros adicionamos 
registros del género y la especie para México y Costa Rica; $\mathrm{y}$, por la primera vez, distribución batimétrica $(0-156 \mathrm{~m})$.

Palabras clave: Asteroidea; Pacífico; México; Costa Rica; nuevo récord.

\section{REFERENCES}

Clark, A.M. \& Downey, M.E. (1992). Starfishes of the Atlantic. London: Chapman \& Hall.Clark, H. L. (1910). The Echinoderms of Peru. Museum of Comparative Zoölogy, 52(17), 321-358.

Hendler, G. (1996). Echinodermata collected at Rocas Alijos. In Rocas Alijos. In. Schmieder Robert W. (ed.), Rocas Alijos. Scientific results from the Cordell Expeditions. Monographie Biologicae (pp. 319-338). London: Kluwer Acad. Publishers.

Honey-Escandón, M., Solís-Marín, F.A., \& LaguardaFigueras, A. (2008). Equinodermos (Echinodermata) del Pacífico Mexicano. Revista de Biología Tropical, 56(3), 57-73.

De Loriol , P. (1900). Notes pour servir à l'étude des échinodermes: seconde série. Georg.VIII. Revue Suisse de Zoologie, 8, 55-96.

Mortensen, T. (1921). Studies on the development and larval forms of echinoderms. Copenhagen: G. E. C. Gad.

Pérez-Ruzafa, A., Alvarado, J. J., Solís-Marín, F.A., Hernández, J. C., Morata, A., Marcos, C., ... \& Barraza, E. (2013). Latin America echinoderm biodiversity and biogeography: Patterns and affinities. In Alvarado J. J., \& Solís-Marín, F. A.(Eds.), Echinoderm research and diversity in Latin America (pp. 511542). Berlin Heidelberg: Springer.

Ziesenhenne, F. C. (1963). A new sea-star from easter island. Annals and Magazine of Natural History, 13 (6), 461-464. 